\title{
COMPUTED TOMOGRAPHIC EVALUATION OF MEDIASTINAL LESIONS
}

P. S. S. Kiran, V. B. Kalra.

1. Senior Resident. Department of Radiodiagnosis, Konaseema Institute of Medical Sciences, Amalapuram, Andhra Pradesh.

2. Professor. Department of Radiodiagnosis, Konaseema Institute of Medical Sciences, Amalapuram, Andhra Pradesh.

\section{CORRESPONDING AUTHOR:}

P.S. S. Kiran,

Department of Radiodiagnosis,

KIMS Medical College,

Amalapuram- 533201.

E-mail: drpsskiran@gmail.com

Ph: 00919490119999

ABSTRACT: AIM: Our objective of study was to characterize the mediastinal lesions on plain and contrast enhanced computed tomography, the distribution of mediastinal masses, the nature of the lesion, enhancement pattern, presence of calcifications and presence of mass effect, the involvement of structures and to compare computed tomography findings with pathological diagnosis wherever possible. The study was performed from August 2012 to February 2013 in the Department of Radio-diagnosis Konaseema Institute of Medical Sciences, Amalapuram, AP on 50 cases with mediastinal pathology which were initially detected on chest radiographs. The maximum number of cases occurred in 4 th - 6 th decade.

In our study of 50 cases of mediastinal masses, the anterior mediastinum was the most common compartment to be involved with (52\%) followed by posterior mediastinum (30\%) and middle mediastinum (18\%).

KEY WORDS: - Computed tomography, Anterior Mediastinum, Middle Mediastinum, Posterior Mediastinum

INTRODUCTION: Computed tomography plays a significant role in the assessment of various mediastinal pathology which were initially detected on the chest radiographs. The maximum number of cases ocamed in $4^{\text {th }}-6^{\text {th }}$ decade. Mediastinal masses occurred commonly in males. In our study of 50 cases of mediastinal masses, the anterior mediastinum was the most common compartment to be involved (52\%) followed by posterior mediastinum (30\%) and middle mediastinum (18\%).

Thymic masses (26.9\%), neural tumors (33.6\%) and metastatic lymph node masses (44.5\%) were the most common mediastinal masses in the anterior, posterior and middle mediastinal compartments respectively.

In the pediatric age group neurogenic tumour was the most common mediastinal mass. Calcification was noted in $(24 \%)$ of cases. Mass effect upon the adjacent mediastinal structures was observed in $(62 \%)$ of the cases and was predominantly noted upon the airways.

Forty three cases (86\%) were histologically verified and four cases $(8 \%)$ of aortic disorders were verified with conventional angiography. Totally 43 cases were verified with histopathology and angiography. With an accuracy of (94\%) forty three cases CT is highly 
us eful modality for investigation of mediastinal masses.

MATERIALS AND METHODS: The study was performed from August 2012 to February 2013 in the Department of Radio-diagnosis Konaseema Institute of Medical Sciences, Amalapuram, AP. Patients referred from Medicine, Surgery and Paediatrics were evaluated through detailed history, necessary physical examination and computed tomography was carried out using Double slice CT scan - GE. Scans were obtained with both Plain and Contrast study.

We classified our mediastinal lesions into three categories as anterior, middle and posterior mediastinal masses.

RESULTS: Our study included 50 cases of mediastinal lesions between age groups 6-76 years. The maximum number of cases occurred in 4th - 6th decade. In our study of 50 cases of mediastinal masses, the anterior mediastinum was the most common compartment to be involved with $(52 \%)$ followed by posterior mediastinum $(30 \%)$ and middle mediastinum $(18 \%)$.

DISCUSSION: The mediastinum is a site for vast range of diseases varying considerably, ranging from tumors both benign and malignant, cysts, vascular lesions, lymph node masses and mediastinitis. Although conventional radiographs can show recognizable abnormalities in many patients with mediastinal abnormalities, in patients with mediastinal pathology radiographs are limited in their sensitivity to delineate the extent of mediastinal abnormalities and the relationship of masses to specific mediastinal structures. With computed tomography these problems are overcome because of its excellent resolution and tomographic format and therefore CT plays an important role in the evaluation of the mediastinum.

Majority of the symptoms were of non-specific nature like cough, chest pain, fever, dysphagia etc. These symptoms were mainly due to mass effect from the mediastinal lesions and were dependent on the location of the mass. Anterior mediastinal masses mostly presented with cough and dyspnea probably due to tracheal compression. Middle mediastinal lesions due to their location presented with dysphagia due to involvement of the esophagus or its compression. Neurogenic tumours account for about (9\%) of primary mediastinal masses in adults, although they are more prevalent in children, constituting $29 \%$ Jof mediastinal tumours. ${ }^{6}$

In our study, anterior mediastinal masses were found to be the commonest accounting for (52 \%). Posterior mediastinal masses accounted for (36\%), followed by middle mediastinal masses accounting for (20\%) of the cases. The cases were analyzed in the following manner as discussed below:

\section{A: Symptoms Distribution}

\begin{tabular}{|l|l|}
\hline \multicolumn{1}{|c|}{ Symptoms } & \\
\hline Cough & $44 \%$ \\
\hline Dyspnea & $36 \%$ \\
\hline Fever & $20 \%$ \\
\hline Chest Pain & $20 \%$ \\
\hline
\end{tabular}


In our study of 52 cases, cough was the most common clinical symptom constituting (44\%) followed by dyspnea (36\%), fever (20\%) and chest pain (20\%).

According to the Davis study in 400 consecutive patients with mediastinal masses, chest pain constituted the most common symptom i.e. (30\%), followed by fever $(20 \%){ }^{8}$

\section{B: Compartmental distribution of mediastinal masses}

\begin{tabular}{|l|l|}
\hline Compartment & Percentage \\
\hline Anterior Mediastinum & $52 \%$ \\
\hline Middle Mediastinum & $18 \%$ \\
\hline Posterior Mediastinum & $30 \%$ \\
\hline
\end{tabular}

In our study of 52 cases, the majority of the mediastinum masses were in the anterior mediastinum constituting ( $52 \%$ ) followed by middle and posterior mediastinal compartment which is similar to the study conducted by Strollo in 1997 wherein anterior mediastinum constituted (50\%) of the masses.7,13

\section{C: Individual masses distribution (Based on the tissue of origin).}

\begin{tabular}{|l|c|}
\hline Neural tumors & 10 \\
\hline Thymic tumors & 14 \\
\hline Lymphoma & 6 \\
\hline Teratoma/GCT & 2 \\
\hline Granuloma & 16 \\
\hline Vascular & 8 \\
\hline Thyroid & 4 \\
\hline
\end{tabular}

In our study Lymphoma constituted (6\%) of the mediastinal masses which is similar to study conducted by Wychulis . $^{1}$

Lymph nodes having a short axis of $2 \mathrm{~cm}$ or more often reflect the presence of neoplasm, such as metastatic tumor or lymphoma, sarcoidosis or infection and should always be treated as potentially significant. Whereas in variety of non infectious and nongranulomatous inflammatory diseases they are usually smaller than $2 \mathrm{cms} .2,3,4$

Malignant lesions have predominated in the male population while benign lesions have occurred with equal frequency in both. Majority of the benign lesions have occurred in between the 2nd and 4th decade. In case of malignancy, majority of the cases have occurred between $4^{\text {th }}$ and 6 th decade.

Lymphoblastic lymphoma is characterized by mass without surface lobulation involving vascular structures often associated with pleural or pericardial effusion, by systemic nodal involvement including cervical, axillary, paraaortic mesenteric and inguinal and by hepatomegaly and splenomegaly. ${ }^{19}$

TUBERCULOUS LESIONS: In our study, tuberculous lesions constituted ( $16 \%$ ), which is greater in comparison to Wychulis study (i.e. 6.3\%) probably due to higher prevalence of tuberculosis in comparison to the western population. ${ }^{1}$ Our study had 3 cases of paravertebral abscess (5.6\%) which was associated with vertebral body destruction.

According to Im study, right paratracheal lymph node enlargement was seen in( $87 \%)$ of cases 
whereas our study showed( $60 \%$ ) involvement. Similarly in Im study 52\% of the lymph node enlargement showed central areas of low attenuation with rim enhancement on contrast study. ${ }^{11}$ Our study showed (40 \%) involvement.

According to Choyke in their study on adult onset pulmonary tuberculosis, reported (40\%) of adults showed presence of pleural effusion, whereas our study showed

(50\%) cases of Tuberculosis associated with pleural effusion. ${ }^{12}$

Hilar and mediastinal lymph node enlargement is commonly seen on CT in active tuberculosis cases, more frequently inchildrenthan adults. 6

THYMIC MASSES: Computed tomography should be the imaging method of choice following plain chest radiograph when suspected thymic abnormality require further evaluation. ${ }^{5}$ In our study the thymic tumors formed the majority with (14\%) which is similar to studies conducted by Cohen and Davis .10,8 In a study by Chen on 34 patients with CT diagnosis of thymic mass, thymoma constituted( $91 \%$ ), thymic cyst (2.9\%) whereas our study of 7 patients with thymic mass, thymoma constituted( $42 \%$ ), and thymic hyperplasia ( $28 \%$ ). ${ }^{9}$

According to Naidich, Thymoma is most commonly seen between 50 - 60 years which is comparable to our study in which the 3 patients with thymoma where of age 40 , 48 years and 48 years respectively. ${ }^{15}$

THYROID MASSES: Intrathoracic goiters are a common cause of mediastinal enlargement. Thyroid masses account for $11-15 \%$ of mediastinal masses. ${ }^{14}$ In our study they represented only (3\%) of the cases. Rounded or irregular, well defined areas of calcification may be seen in benign areas, whereas amorphous cloud like calcification is occasionally seen within carcinomas. $^{20}$

ANEURYSM OF THORACIC AORTA: Aortic aneurysms can result in a mass in the anterior, middle or posterior mediastinum. The classical description of aortic aneurysm is an area of permanent dilatation of the aorta where the dilatation is at least $50 \%$ greater than baseline or standardized normal limits. ${ }^{16}$

PLEUROPERICARDIAL CYST: They result from aberrations in the formation of coelomic cavities. Pericardial cysts are invariably connected to the pericardium. Majority of them arise in the anterior cardiophrenic angle, more frequently on the right, but can be seen as high as the pericardial recesses at the level of the proximal aorta and pulmonary arteries.$^{17} \mathrm{CT}$ shows thin walled unilocular water density $(0-20 \mathrm{HU})$ cystic structure. Wall may calcify.

BRONCHOGENIC CYST: Bronchogenic cysts are congenital lesions thought to result from abnormal budding of the embryonic foregut. Most cysts are located in the mediastinum, near the tracheal carina predominantly in the middle mediastinum (79\%) less commonly may occur within the lung parenchyma, pleura or diaphragm (15\%) according to McAdam's series. ${ }^{18}$ 


\section{CLASSIFICATION OF MEDIASTINAL MASSES- Based on Location 21}

\begin{tabular}{|c|c|c|}
\hline & Common lesions & Rare lesions \\
\hline $\begin{array}{l}\text { Anterior } \\
\text { mediastinum }\end{array}$ & $\begin{array}{l}\text {-Tortuous brachiocephalic } \\
\text { vein } \\
\text { - Lymph node enlargement } \\
\text { - Retrosternal goiter } \\
\text { - Fat deposition } \\
\text { - Thymic tumour } \\
\text { - Germ cell } \\
\text { - Epicardiac fat pad tumours } \\
\text { - Diaphragmatic hump } \\
\text { - Pleuropericardial cyst }\end{array}$ & $\begin{array}{l}\text { - Aneurysm of } \\
\text { brachiocephalic } \\
\text { artery } \\
\text { - Lymphangioma } \\
\text { - Parathyroid } \\
\text { adenoma } \\
\text { - Sternal mass } \\
\text { - Lipoma } \\
\text { - Haemangioma } \\
\text { - Morgagni hernia }\end{array}$ \\
\hline $\begin{array}{l}\text { Middle } \\
\text { mediastinum }\end{array}$ & $\begin{array}{l}\text { - } \quad \text { Lymph node enlargement } \\
\text { - Aneurysm arch aorta } \\
\text { - Enlarged pulmonary artery } \\
\text { - Dilated superior vena cava } \\
\text { Bronchogenic cyst }\end{array}$ & $\begin{array}{l}\text { - } \text { Tracheal lesions } \\
\text { - Cardiac tumours }\end{array}$ \\
\hline $\begin{array}{l}\text { Posterior } \\
\text { mediastinum }\end{array}$ & $\begin{array}{l}\text { - } \text { Neurogenic tumours } \\
\text { - Hiatus hernia } \\
\text { - } \text { Aneurysm of descending } \\
\text { artery } \\
\text { - } \quad \text { Oesophageal masses } \\
\text { - } \quad \text { Dilatation of azygos vein } \\
\text { - Para vertebral mass }\end{array}$ & $\begin{array}{l}\text { - } \quad \text { Neurenteric cyst } \\
\text { - } \quad \text { Pseudocyst of } \\
\text { - } \quad \text { Sequereas } \\
\text { - } \text { Thoracic duct cyst } \\
\text { - } \quad \text { Bochdalek hernia } \\
\text { - } \quad \text { Extramedullary } \\
\text { - } \quad \text { hemopoiesis } \\
\text { Thoracic duct cyst }\end{array}$ \\
\hline \multicolumn{3}{|c|}{$\begin{array}{l}\text { Thoracic aorta passes through all the divisions of mediastinum. Hydatid cyst can occur } \\
\text { most commonly in the middle and posterior mediastinum. Masses situated in all mediastinal } \\
\text { compartments are lymphoma and sclerosing mediastinitis }\end{array}$} \\
\hline
\end{tabular}




\section{Compartmental distribution of mediastinal lesions}

\begin{tabular}{|l|c|c|}
\hline Compartment & No of Cases & Percentage \\
\hline Anterior Mediastinum & 26 & 52 \\
\hline Middle Mediastinum & 9 & 18 \\
\hline Posterior Mediastinum & 15 & 30 \\
\hline
\end{tabular}

\section{Anterior Mediastinal Lesions distribution}

\begin{tabular}{|l|c|c|}
\hline & NO of CASES & Percentage \\
\hline Thymic masses & 7 & 26.9 \\
\hline Metastatic lymph Node & 5 & 19.2 \\
\hline TB Lymph Node & 4 & 15.4 \\
\hline Aortic Mass & 4 & 15.4 \\
\hline Lymphoma & 3 & 11.6 \\
\hline Thyroid Mass & 2 & 7.7 \\
\hline Germ cell Tumour & 1 & 3.8 \\
\hline Total & 26 & 100 \\
\hline
\end{tabular}

Middle mediastinal Lesions distribution

\begin{tabular}{|l|c|c|}
\hline & No of cases & Percentage \\
\hline Metastatic Lymph Node & 4 & 44.5 \\
\hline TB Lymph Node & 2 & 22.2 \\
\hline Neuroenteric cyst & 1 & 11.1 \\
\hline Esophageal Duplication Cyst & 1 & 11.1 \\
\hline Bronchogenic cyst & 1 & 11.1 \\
\hline Total & 9 & 100 \\
\hline
\end{tabular}

Posterior mediastinal lesions distribution

\begin{tabular}{|l|c|c|}
\hline & No of masses & Percentage \\
\hline Neural tumors & 5 & 33.3 \\
\hline Para vertebral abscess & 3 & 20 \\
\hline TB Lymph Node & 2 & 13.3 \\
\hline Oesophageal mass & 2 & 13.3 \\
\hline Hydatid cyst & 1 & 6.7 \\
\hline Para vertebral hematoma & 1 & 6.7 \\
\hline Lymphangioma & 1 & 6.7 \\
\hline Total & 15 & 100 \\
\hline
\end{tabular}

\section{REFERENCES:}

1. Wychulis AR, Payne WS, Clagett OT et al. Surgical treatment of mediastinal tumors: a 40 year experience. J Thorac Cardiovas Surg 1971; 62: 379-92.

2. Andonopoulos AP, Karadanas AH, Drosis AA et al, CT evaluation of mediastinal lymph nodes in primary Sjogren syndrome. J Comput Assist Tomogr 1988; 12: 199201.

3. Abele DR, Gamsu G, Lynch D. Thoracic Manifestations of Wegener's Granulomatosis, diagnosis and course, Radiology 1990; 174: 703-9 
4. Bergein C, Castellino RA, Mediastinal Lymph Node Enlargement on CT scans in patients with unusual interstitial pneumonitis, AJR, Am J Roentgenol 1979; 132: 17 21.

5. Baron RL, Lee JKT, Sagel SS, Peterson RR. Computed Tomography of the normal thymus. Radiology 1982; 142: 121-5

6. Ribet ME, Cardot GR. Neurogenic tumors of the thorax. Ann Thor Surg 1994;58: 1091-5.

7. Strollo DC, Rosado de Christenson ML, Jett JR. Primary mediastinal tumors. Part I. Tumors of the anterior mediastinum. Chest 1997; 112: 511-22.

8. Davis et al. Primary cysts and neoplasms of the mediastinum: Recent changes in clinical presentations, methods of diagnosis, management and results. Ann Thorac Surg 1987; 44: 229-37.

9. Chen J, Weisbrod GL, Herman SJ. Computed tomography and pathologic correlations of thymic lesion. J Thorac Imaging 1988; 3: 61-5.

10. Cohen AJ, Thompson LN, Edwards FH et al. Primary cysts and tumors of the mediastinum. Ann Thorac Surg 1991; 51: 378-86.

11. Im JG, Itoh H, Shim YS et al. Pulmonary Tuberculosis: CT findings early active disease and sequential change with antituberculous therapy. Radiology 1993; 186: 653-60.

12. Choyke PL, Sostaman HD, Curtis AM et al, Adult onset pulmonary tuberculosis. Radiology 1983: 148: 357-59..

13. Strollo DC, Rosado de Christenson ML, Jett JR. Primary mediastinal tumors: Part II, Tumors of the middle and posterior mediastinum. Chest 1997; 112: 1344-57.

14. Prasad A. et al., .Computerized tomographic evaluation of mediastinal lesions - Pictorial assay, Ind J Radiol Imag; 2001, 11:65-70.

15. Naidich DP,Webb WR, Muller NL, Zerhouni EA, Seigelmann SS. Mediastinum, Chapter 2 In: Naidich DP, Muller NL, Zerhouni EA, Webb WR, Krinsky GA (eds) Computed tomography and Magnetic Resonance of the thorax, $3^{\text {rd }}$ edition, Lippincott Williams and Wilkins, Philadelphia, 1999: 38-160.

16. Nguyen BT. Computed tomography of thoracic aortic aneurysms. Seminars in Roentgenology 2001; 36 (4): 309-24

17. Jeung MY, Gasser B, Gangi A et al. Imaging of cystic masses of the mediastinum. Radio graphics 2002; 22: 579-93.

18. McAdams HP, Kirejczyk WM, Rosado de Christenson ML et al. Bronchogenic cyst: Imaging features with clinical and histopathologic correlation. Radiology 2000; 217: 441-46.

19. Tateishi U, Muller NL, Johkoh $\mathrm{T}$ et al Primary mediastinal lymphoma characteristic features of the various histological subtypes on CT. J Comput Assist Tomogr 2004; 28 (6): 782-89.

20. Armstrong R, Padley SPG. The mediastinum, Chapter 17 In: Grainger RG, Allison D, Adam A, Dixon AK (eds), Diagnostic radiology, Vol. $1,4^{\text {th }}$ edition, Churchill Livingstone, London, 2001: 353-76.

21. Gregson RHS, Whitehouse RW, Wright AR, Jenkins JPR. The mediastinum, Chapter 2 In: Sutton P (ed) Textbook of Radiology and Imaging, Vol. $1,7^{\text {th }}$ edition, Churchill Livingstone, London, 2003: 57-86. 


\section{Compartmental distribution of mediastinal lesions}

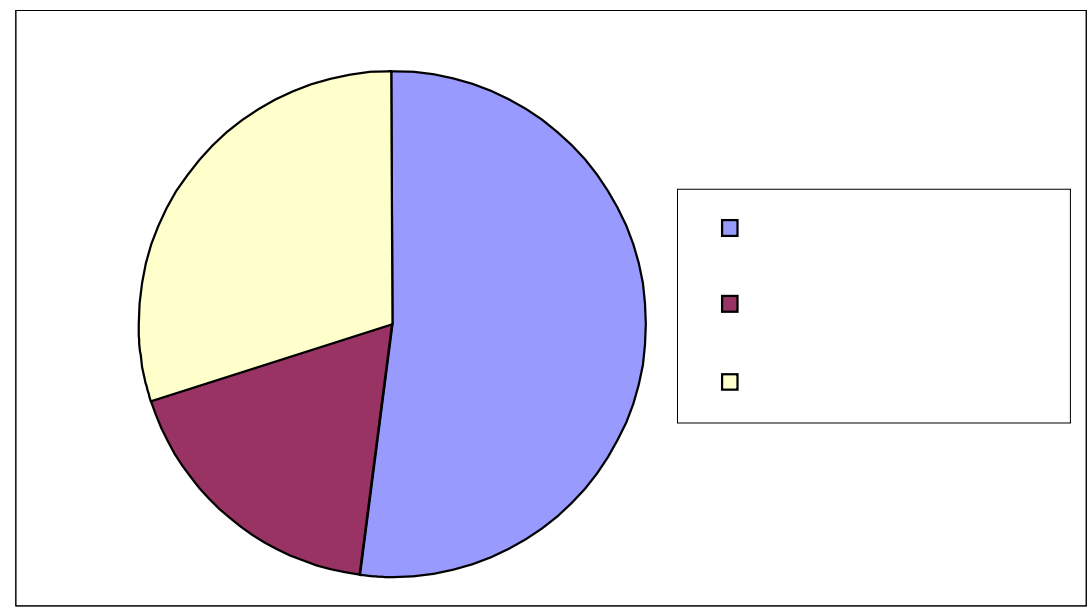

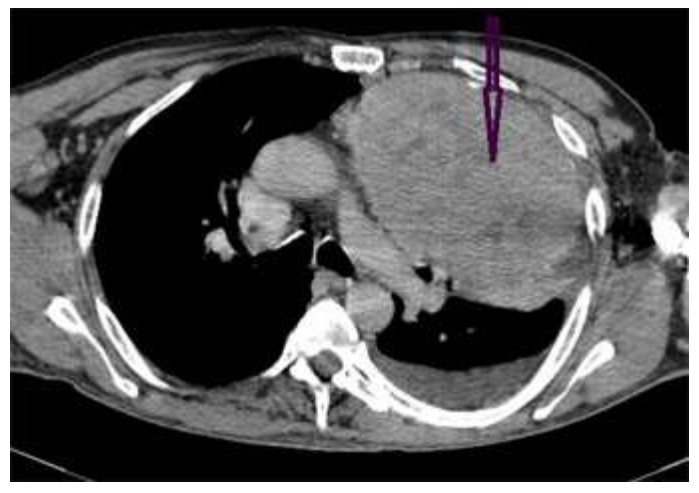

FIGURE 1- CECT showing lobulated anterior mediastinal mass with mixed attenuation. --THYMOMA

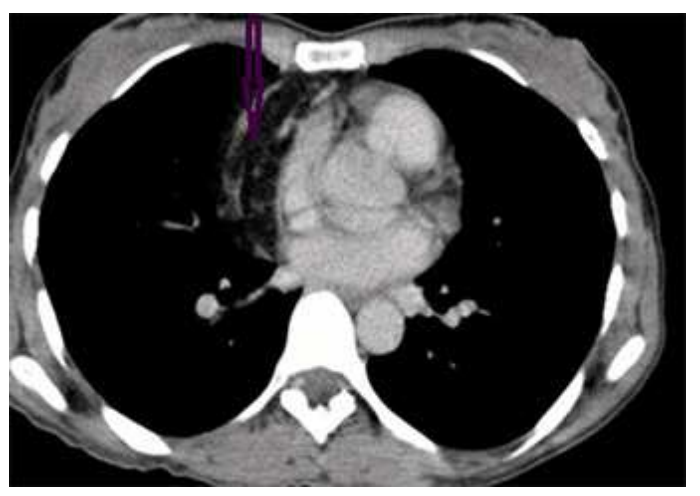

FIGURE 2- CECT showing anterior mediastinal mass with fat density and some areas of inhomogeneous soft tissudensity.THYMOLIPOMA 


\section{ORIGINAL ARTICLE}

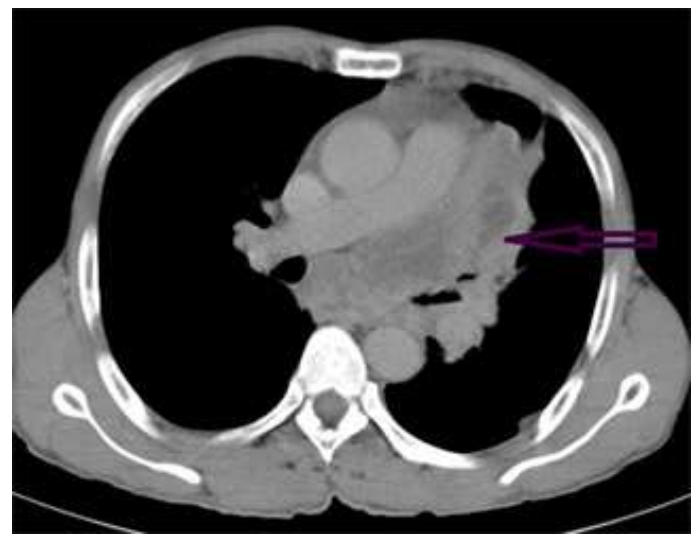

FIGURE 3-CECT showinh left hilar mass with moderate heterogenous enhancement.---Carcinoma lung with mediastinal lymphadenopathy

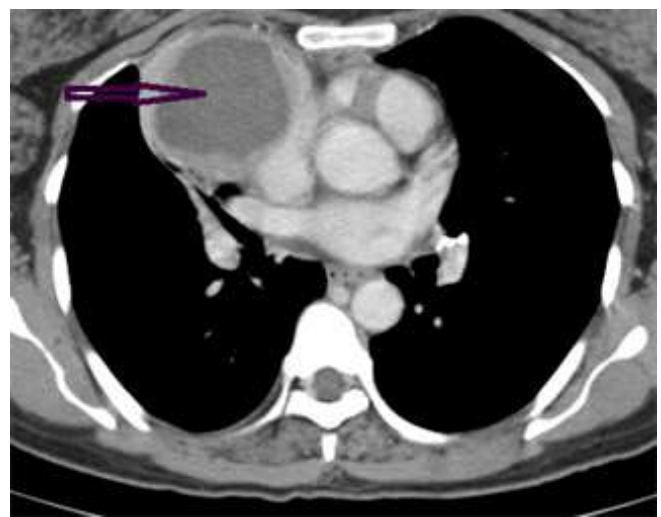

FIGURE 5- CECT showing cystic right anterior mediastinal mass with peripheral rim enhancement.----THYMIC CYST

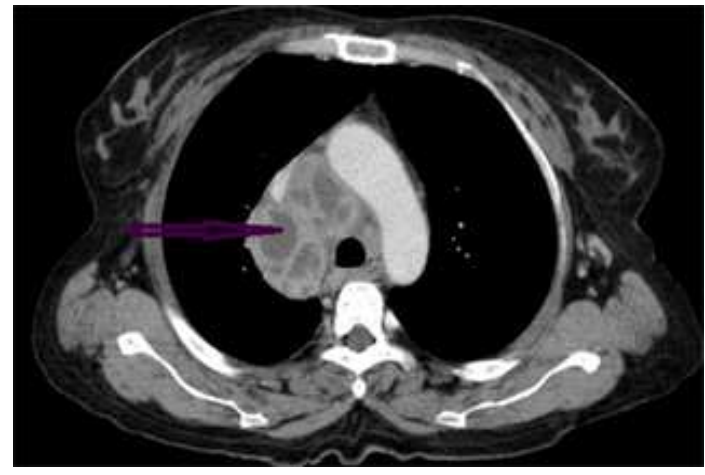

FIGURE 7-CECT showing central necrotic areas with rim enhancing lesions in middle mediastinum.-TUBERCULAR LYMPHADENOPATHY

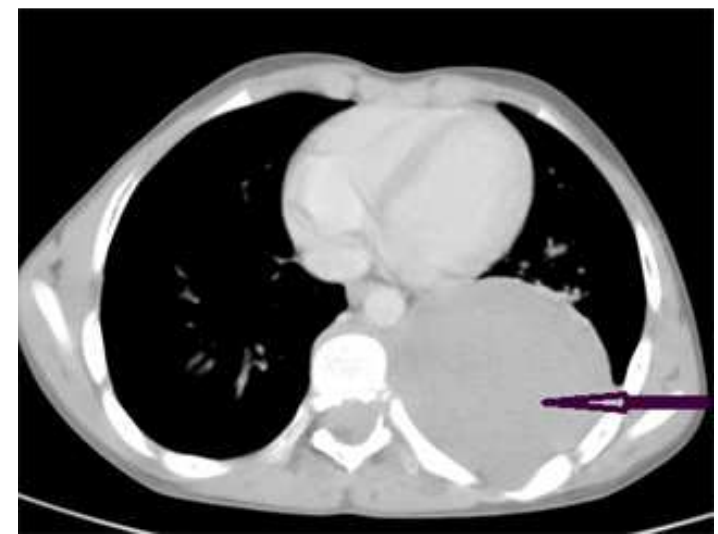

FIGURE 4- CECT showing poorly

enhancing homogenous, soft-tissue attenuation mass in left paravertebral region.-------NEUROGENIC TUMOUR

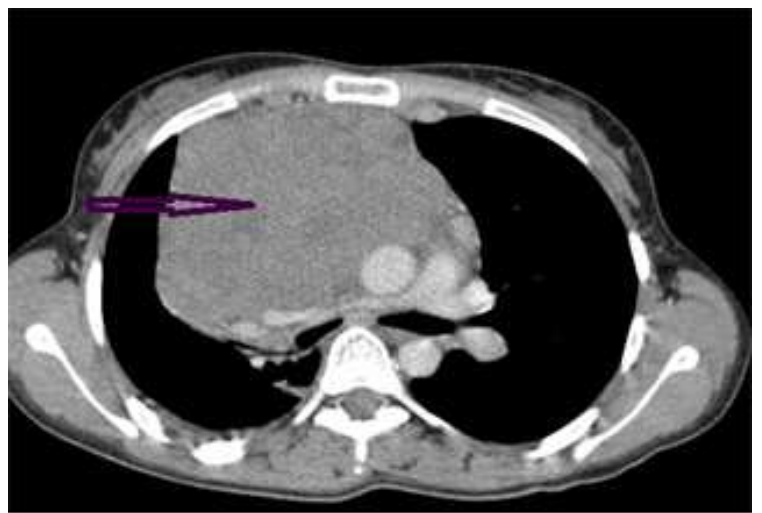

FIGURE 6- CECT showing lobulated heterogenously enhancing anterior mediastinal mass on right side.--HODGKINS LYMPHOMA

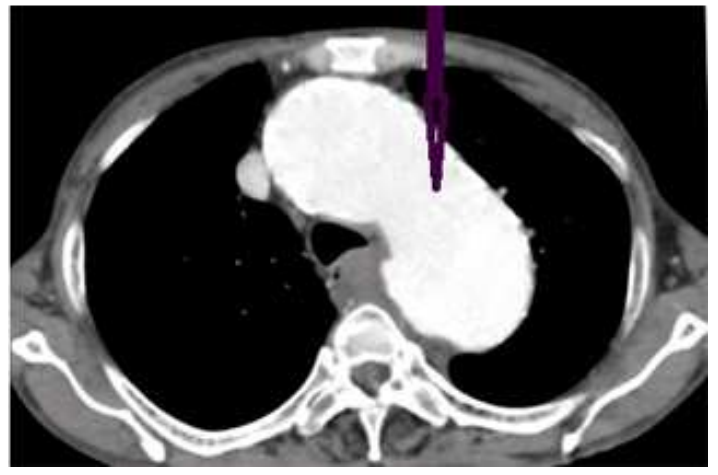

FIGURE 8-CECT showing aneurysm of arch of aorta 


\section{ORIGINAL ARTICLE}

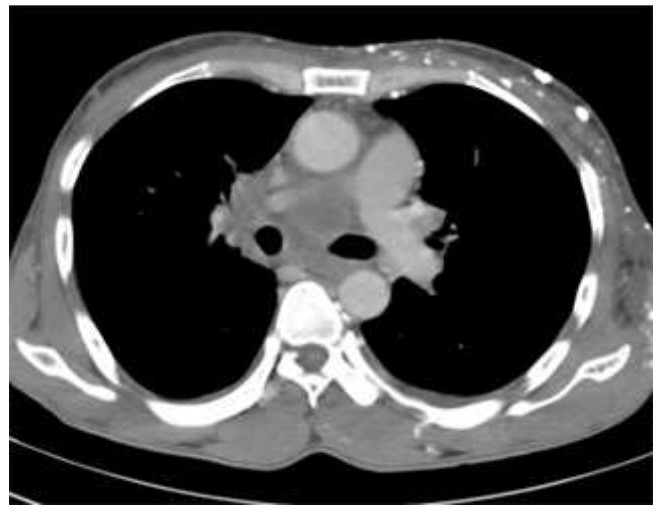

Metastatic lymphadenopathy

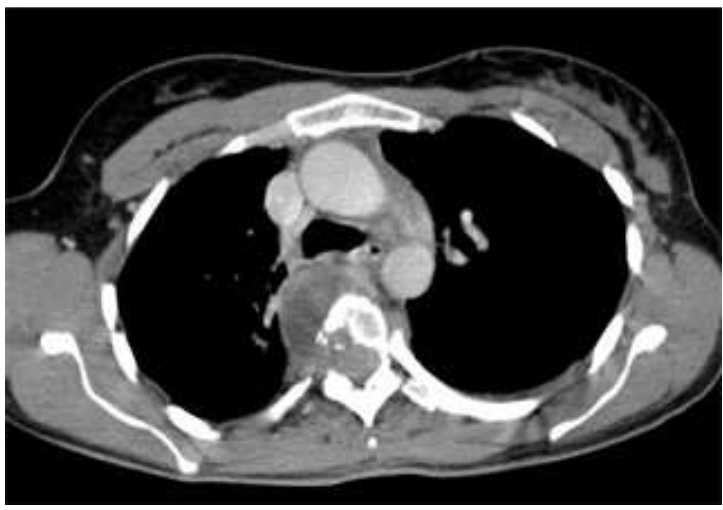

TB spine with paravertebral abscess

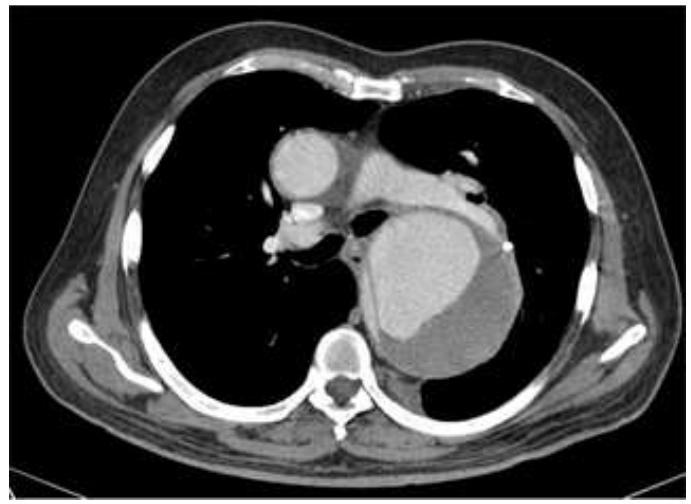

Aortic dissection

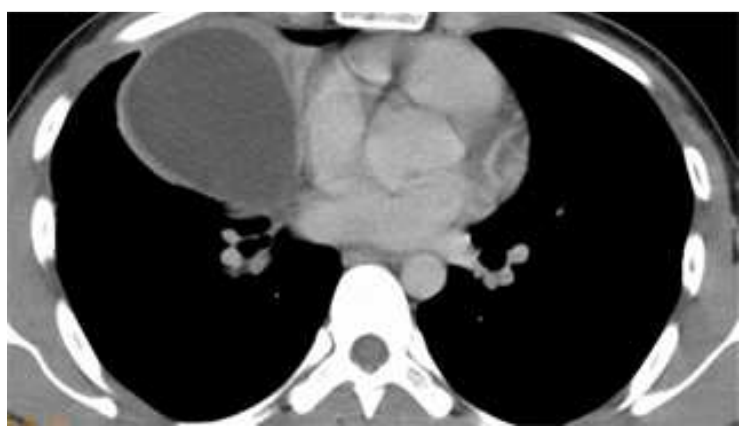

Bronchogenic cyst

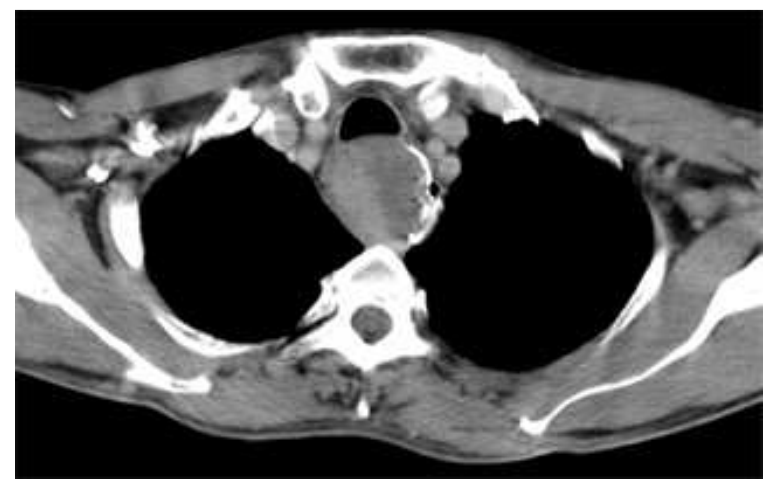

Carcinoma esophagus 